\title{
Karen Tuttle's Coordination applied to the performance and interpretation of Edino Krieger's Brasiliana
}

\author{
Leonardo Piermartiri | Universidade do Estado de Santa Catarina | Brazil \\ Daphne Capparelli Gerling | University of North Texas | USA
}

\begin{abstract}
Resumo: Este artigo tem como objetivo a aplicação de Coordination, o conjunto de técnicas e princípios desenvolvidos pela violista Karen Tuttle, na interpretação de Brasiliana para Viola e Cordas de Edino Krieger. Os princípios centrais de Coordination são realizados através de movimentos físicos no corpo do instrumentista para conectar as intenções emocionais e musicais da interpretação. Para esse estudo foi realizada uma entrevista interativa com a Profa. Susan Dubois, antiga assistente pedagógica de Tuttle na Juilliard School of Music, e uma das principais professoras dessas técnicas. Após uma breve revisão do histórico de Tuttle, suas técnicas, e da obra em questão, são apresentados excertos da parte da viola solo com notações de sugestôes interpretativas aplicando essas técnicas.
\end{abstract}

Palavras-chave: Karen Tuttle's Coordination, Edino Krieger, Brasiliana, Viola Performance, Music Performance.

\begin{abstract}
This article focuses on the application of Coordination, a set of principles and techniques developed by the late violist Karen Tuttle, as applied to the performance of Brasiliana for Viola and Strings by Edino Krieger. Coordination occurs in performance through specific physical motions of the performer's body that connect the emotional and musical aspects of the interpretation. This study draws on interview content with Dr. Susan Dubois, Tuttle's former teaching assistant at the Juilliard School of Music, and a leading exponent of her teaching. After a brief background on Tuttle's techniques and on the piece itself, annotated excerpts of the solo viola part are provided, with suggested interpretative markings applying these techniques.
\end{abstract}

Keywords: Karen Tuttle`s Coordination, Edino Krieger, Brasiliana, Viola Performance, Music Performance. 
merican violist Karen Tuttle $(1920-2010)$ had an intense and fruitful career as a
performer and pedagogue, reaching the highest milestones in a musician's career. In
addition to performing with the greatest artists of her time she gave solo recitals, including at Carnegie Hall in 1960, and taught at the Juilliard School of Music, Curtis Institute, and Peabody Conservatory among others. Though her performing career was stellar, her personal approach to playing the viola is her most important legacy, a combined set of principles and techniques developed and perfected throughout her life that she later called Coordination. Tuttle did not conceive Coordination as a written method; it is the result of her own pursuit of what she called the essential "Truth" in music making. According to Rodland (2004, p. 45) Tuttle found that "Truth" in six people: her teacher, violist William Primrose, the cellist Pablo Casals, former Philadelphia Orchestra principal oboist Marcel Tabuteau, the violinist Alexander Schneider, the physician and violinist Demetrius Constantine Dounis, and the work of psychoanalyst Wilhelm Reich. They all were key influences in the development of her concepts.

In the early 1940 s her career as a high-level freelancing violinist in Hollywood took a turn when she attended a concert given by William Primrose. He had a natural way of playing, with great ease and virtuosity. She thought he was the most beautiful image of anyone playing an instrument (RITSCHER, 1993, p. 86). After talking to him, she decided to join his class at the Curtis Institute in Philadelphia and switch to the viola. During those years she was able to closely observe Primrose's playing and soon he asked her to become his assistant. He would often send his students to her because she could articulate in words the technical details of playing that he could only beautifully demonstrate. When Primrose left Curtis to focus on his career, she was offered his teaching position.

Tuttle met the famous cellist Pablo Casals in 1950 at the Prades Festival and immediately after that she decided to stay another six months in France to study with him. Like Primrose, Casals was a very intuitive player and performer and by constantly observing their playing she was able to "decode" the mechanics of their movements. What called her attention in Casals was the way he conducted his body to convey the emotions and musical intention. By learning his approach to playing his instrument, she had another moment of "Truth." He taught her the moto "If it hurts it is wrong" which paved the way to her approach of "pain-free playing" (WEINBERGER, 1998, p. 67). With Casals she also learned to deepen the emotional aspect of performing and to develop a connection 
with the character of the music even before learning a new work. As a result of this, years later she created her list of emotions (IRVINE et al, 2020, p. 167), a pedagogical tool designed to help students and performers identify the music's inherent characters.

Tuttle played with Alexander Schneider in the Schneider Quartet and they recorded a great number of Haydn's quartets. Schneider influenced Tuttle mostly in the approach to musicality and sense of phrasing. She had great admiration for him and his musicianship, although she thought he could sometimes be quite rude. Oboist Marcel Tabuteau was also the conductor for the string orchestra at the Curtis Institute, and there Tuttle had contact with his ideas of note grouping (RITSCHER, 1993, p. 86). He created a system of organizing the notes within the phrase in a way that it is not dictated by the bar-line, thus giving direction to the musical intention.

Another important influence in Tuttle's development of pain-free playing was her contact with the medical doctor Demetrius Constantine Dounis. In the five extensive lessons she had with him, he taught her the concepts of stance and of balancing the instrument as opposed to clutching it. He would work the whole body going through every aspect, from the feet to the neck. Tuttle said that he was able to verbalize everything she had learned from watching Primrose (WEINBERGER, 1998, p. 67). Also, in the 1950s Tuttle became familiar with Wilhelm Reich's ideas and writings through her husband, a psychoanalyst of that lineage. From then on, she started applying the concept of tension and release to playing the viola, connecting the physical as well as the emotional aspects of making music.

Tuttle's approach based on these experiences led to what she later named Coordination. As described by Dew, "Coordination operates in the sonic transmission of emotion", it denotes a relationship between the horizontal movement of the bow with discrete movements of the neck, shoulders, chest, and pelvis (DEW, 1993, p. 835). Dew's article, published in 1993, was the first written document that thoroughly explained the concepts and principles on which Coordination is based. Reiter describes it in a similar way:

In this technique, there is a constant cycle of muscular releases of two body parts: the neck and the pelvis or lower back. According to Karen Tuttle, once the player has assimilated the physical aspect of these releases, he or she will then be able to translate them into powerful musical expressions. (REITER, 2008, p. 4). 
Since Tuttle passed away and left behind a very small amount of documentation, a few dissertations have been written concerning her legacy and pedagogy with special attention to Dane (2002), and Sander (2013). Sander wrote her dissertation to create a comprehensive educational guide to the motions of Coordination. To open the study of Coordination to a much broader population she applied these techniques to Ernest Bloch's Suite Hébraïque for Viola, a piece that is in the worldwide standard repertoire for the viola. Inspired by her research and process of inquiry, this article seeks to provide a Coordination performance guide to Brasiliana, making this piece more accessible and known to the international viola community.

Among the works written for viola by Brazilian composers in the XX century, Brasiliana by Edino Krieger has become part of the standard viola repertoire in Brazil (BIAGGI, 1996, p. 62) and is arguably one of the most performed and studied by violists, both professional and advanced students. Its melodious opening theme comes from a folkloric source, giving the piece a strong nationalistic character. Several short virtuosic passages add to the excitement of the work in its final section. The original score ${ }^{1}$ calls for a string orchestra, allowing for greater ease in programming live performances. The orchestration allows the work to be performed also by a string quartet accompaniment in recital settings.

\section{Coordination Techniques}

In the process of creating this performance guide, the authors wished to explore several key concepts of Coordination. These include specifically: neck releases, repull, downward and upward gestures, and grouping. ${ }^{2}$ While each element of coordination is described separately, it is fundamental to understand that these motions occur in a flowing continuum when performed, and are subject to the infinite nuance and variation of each performer's approach. Most importantly, they need to be subtle as to not detract from the music and performance and should also be refined and minimized the more comfortable one becomes with them.

\footnotetext{
${ }^{1}$ The score used in this study is a digital transcription made by Rafael Videira, its use has been granted.

2 This study omits the study of left-hand rebalance, a key concept of coordination applied to fingering that connects the balance of the left-hand fingers with the positioning of the left wrist and elbow and significantly influences intonation and vibrato.
} 
Neck Release: neck releases entail the temporary motion of the head and neck lifting slightly back and up without fully coming away from the instrument. The weight of the head is pivoted on the chinrest but never loses contact with it. ${ }^{3}$ The motion is a catalyst for other motions of coordination in that it creates a release in the spine, chest, pelvis, lower back, and knees. The intensity, size and duration of neck releases while playing is variable and can be adapted to a variety of musical contexts. The key importance of the neck release in coordination is its nearly constant use. Neck releases can occur in at least six different contexts: bow changes at the frog or tip, chords, shifts, string crossings, ties, and dotted notes. For many violists studying in the Tuttle lineage, this is the first motion of coordination they are taught, as it generates the understanding and connection necessary for learning the other motions.

Repull: Repull refers to the action of the right-hand wrist and fingers, primarily on a downbow stroke. Its purpose is to intensify the sound, when musically needed, as the stroke goes from the lower, stronger part of the bow, to the upper half, which is naturally weaker. The action consists in softening the bow-hold before the balance point, allowing the right hand fingers to fold again (and the wrist to lower), re-engaging the pronated angle of the right hand, and re-applying weight to the bow before it reaches the middle of the bow. Different Tuttle pedagogues make use of this technique with some variations, primarily related to the degree of supination and pronation involved. Repulls can occur at any point in the bow, and reverse repulls can occur on up-bows, but their fundamental use is on the down-bow, at the balance point, to increase the ability to sustain the sound.

The Coordination of Upward and Downward Gestures: A key motion connecting bow changes is the use of neck releases to prepare the bow change in either direction. A crucial element to understanding this is the idea that players begin in a centered, balanced stance. When initiating the bowing pattern with down-bow, they move below a "midpoint" of their center, returning in the middle. In the upper half of the bow one extends above the midpoint, returning again in the middle of the bow. The coordinated placement of these releases in either direction results in the following motions:

Upward Motion is also referred to as Up and Over/Going Over/ Over the tip of the bow: On the down-bow in the upper half, in preparation of the up-bow, the performer extends from the

\footnotetext{
${ }^{3}$ See Sander, 2013, p. 25.
} 
midpoint of a balanced stance, with an upward neck release and an upward clockwise circular motion of the right hand connecting the down-bow to the up-bow. The bow change to up-bow is rounded. The neck releases downward after the bow change is complete.

The natural consequence of going over the bow is to generate a legato bow change at the tip. In the resulting up-bow that follows, the player engages in the next motion discussed here:

Physically leading through the up-bow: When physically leading through the up-bow to prepare the down-bow, the performer leads the up-bow from a rooted, balanced stance (feet) by physically extending the torso from the midpoint of a balanced stance, usually on an inhale. Upon arrival at the balance point, the neck and chest release prepare the return to the down-bow, allowing the right hand and arm to follow through. Upward motion facilitates the creation of space across the collar bone, pectoral muscles, and neck. When the up-bow is properly led by the elbow and wrist, the right hand clears the C-bout and bridge, resulting in a smooth and continuous bow change. If dynamic power is desired, it is easily achieved. If a subtle, quieter tone is needed, the motion contributes to the nuanced use of weight and flexibility of the right hand, wrist, and fingers.

Downward Motion: In the first half of the down-bow, from frog to middle, downward motion connects from the neck release that initiated that bow, allowing the softening or release of the chest, torso, pelvis, lower back, and knees. This is often referred to as "going under" or "melting". The purpose of the downward motion is "to create depth and direction in the sound" (SANDER, 2013, p. 19). The downward motion can be used in conjunction with the repull at the balance point. It most often occurs on an exhale, and always on a down-bow.

\section{Marking and annotations for Coordination}

The notation of Coordination is not rigidly standardized. Tuttle herself never determined that there was a "correct" or "official" approach to marking physical, emotional or musical intentions in music. The few documents (Irvine et al, Reiter, Sander) that present this notation all have slight differences, confirming that it is up to each interpreter to notate what body movements will best serve their needs. 
For this study, Leonardo Piermartiri interviewed and worked interactively with the eminent Tuttle pedagogue Dr. Susan Dubois, Tuttle’s former teaching assistant at the Juilliard School of Music. She noted that she does not teach Coordination per se the same way to every student, because there is no set way to teach it. The timing of how one introduces the various concepts and ideas can be very different depending on the student's needs and on the music taught. Often, concepts will be introduced when a student starts a new piece. For example, to get a sustained sound she will talk about "filling up" a note using the downward motion, which she most often refers to as "melting." The use of this intensification of the sound in a dotted note is a common instruction by Tuttle and it can be seen in the opening phrases of Schubert's Arpeggione and Brahms Sonata op. 120 n. 2 in E-flat major (REITER, 2008, p. 37 and 68). Dubois recalled Tuttle teaching her this concept when she was first introduced to Coordination, at the time she was learning this Brahms Sonata.

Among the points Dubois emphasized in her own approach to teaching coordination were:

- beginning by teaching bow changes, connecting "down and under" and "up and over." What connects these gestures is the Coordination, the big, long continuous waves of the bow arm. The purpose of these motions is to connect depth of sound, weight and balance, spinning tone and resonance.

- teaching a figure eight (sideways infinity loop) in the bow arm motion.

Daphne Gerling also teaches in this way, emphasizing the correlation of the quadrants of the figure of eight with the different stages of coordinated motion. The sequence is as follows:

Begin in a balanced stance (mid-point or middle axis.) Don't get stuck in either the released downward or extended upward position.

1) Down-bow, frog to middle: downward motion, convex motion of right arm

2) Down-bow, middle to tip: neutral midpoint to upward motion, concave motion of right arm, preparing "over the bow"

3) Up-bow, tip to middle: following "over the bow" and arriving in the middle or the bow at the mid-point (balanced stance.) 
4) Up-bow, middle to frog: physically leading through the up-bow with torso, continuing seamlessly as the upward motion creates the neck release at the balance point, which prepares the bow change.

The combination of these motions can be summarized as "Center-down/melt-center; Center up/lead, center. These can be interpreted visually using Margaret Pardee's illustration.

FIGURE 1 - Margaret Pardee's illustration of figure 8.

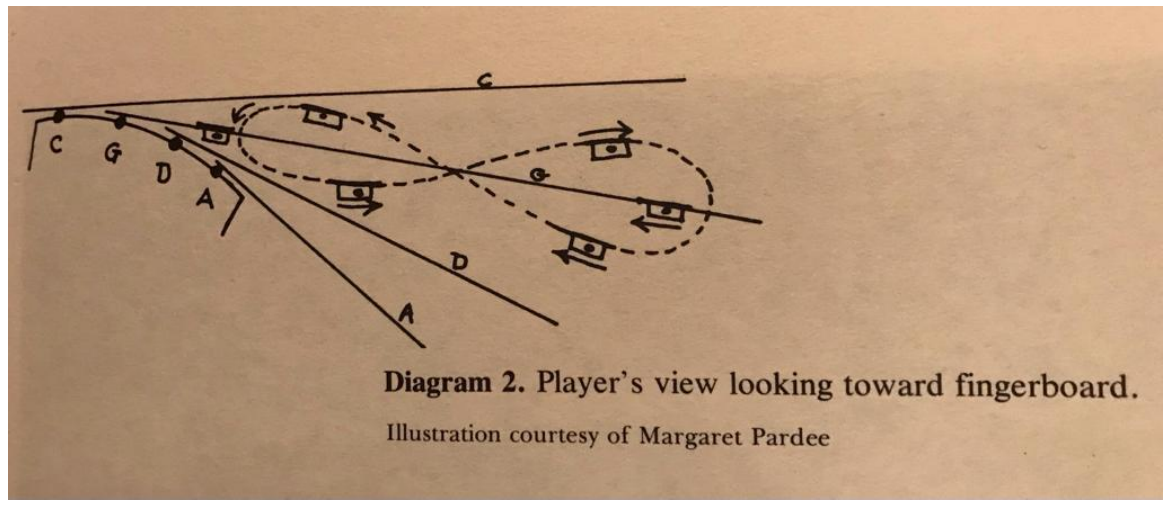

Source: BARRETT (1978, p. 81).

These are also important points to consider when performing these motions:

- maintaining a consistent contact point and good sound production, otherwise the motions will not achieve the desired result in sound quality.

- Coordination should not be guided by the bowing; it is the phrasing that will determine the Coordination and the bowing.

According to Dubois, the markings presented in The Karen Tuttle Legacy (2020, p. 108-111) represent most closely what Tuttle herself would describe with her hands during lessons. Dubois recalls that: 
These body gestures that Tuttle used to allude with her hands are the same ones that Sander later described as the downward and the upward gestures (SANDER, 2013, p. 19-23).

Dubois noted that "Tuttle believed only $10 \%$ of people truly internalize Coordination. So, she preferred that people exaggerate some form of the gestures when learning, rather than playing with excessive tension.” Dubois teaches Coordination by finding the groupings, the musical gestures, and asking specific questions. "Where is the musical line going to?" "What is the climax, and how do I get there?" If the student does not know what to do, she suggests trying one gesture, for example going down and then trying the opposite (or choosing a musical direction), "One option is going to feel better and sound better. It is a process of trial and error” (DUBOIS, 2020).

\section{About Brasiliana and Edino Krieger}

Edino Krieger (b. 1928) is one of the preeminent figures in the Brazilian musical scene, having a distinguished career as a composer, musical producer, reviewer, and journalist. While his compositional output is vast, covering a full spectrum of genres, he is especially known for his orchestral and chamber music works.

Born in Brusque, Santa Catarina, Brazil, into a family of musicians, Krieger was introduced to the violin at an early age. By 1943, aged 14, he already displayed early signs of virtuosity and therefore received a scholarship to study at the Conservatório Brasileiro de Música in Rio de Janeiro. There he met the German composition professor Hans-Joachim Koellreutter and began attending his class. Koellreutter had moved to Brazil to flee the Nazi persecution for defending the Jewish cause. He was one of Brazil's most influential musicians, introducing the new compositional techniques and theories developed in Germany in the first half of the $20^{\text {th }}$ century, dodecaphonism, atonality and serialism. Krieger became so immersed in his study of these techniques that his studies on the violin were soon eclipsed by it. Some of his colleagues in Koellreutter's class where established composers like Cláudio Santoro and César Guerra-Peixe. This close contact tremendously enhanced Krieger's experience. By 1945 he had joined Música Viva, a group founded by Koellreutter to promote and disseminate the production of Brazilian contemporary music and in 1948 he was selected by Aaron Copland and received a scholarship to study composition at the Berkshire Music Center in 
Massachusetts. In addition to study composition with Aaron Copland, Peter Mennin and Darius Milhaud, he also studied violin with New York Philharmonic violinist William Nowinski.

According to Berbert and Biaggi (p. 536 apud PAZ), Krieger's overall work is noted by a great formal balance and diversity of genres, styles and ensemble formations and is usually divided in three phases:

a) Experimentalist and Universalist (1945-1952): breaking with the romantic and impressionistic tendencies of his adolescence, this phase was triggered by the discovery and use of the dodecaphonism and serialist techniques.

b) Neoclassic and Nationalist (1953-1965): influenced by Copland, Milhaud, Mennin and Krenek he turned to a neoclassic approach combining classical forms with Brazilian urban genres (choro, frevo, seresta). He also displays greater harmonic freedom transiting between tonal and modal, frequently employing Mixolydian and Lydian modes from the Northeastern part of Brazil.

c) Dialectic Synthesis and Full Compositional Freedom (1966-): marked by a total freedom in the use of techniques, forms and compositional process and a search for national traits, seeking a harmonious combination of tradition and vanguard.

Composed in 1960, Brasiliana for Viola and Strings is a clear example of Krieger's nationalistic phase. It was commissioned by George Kiszely (1930-2010), a Hungarian violist resident in Brazil, and it was premiered in the same year by Kiszely and the Orquestra Sinfônica Brasileira conducted by Krieger himself.

In an interview with Biaggi in August 1992, the composer mentioned that Brasiliana "was the only piece he ever wrote that uses a theme borrowed from the folklore." The piece starts with a recitative and it is this melody that Krieger heard at a festival that gathered folk singers and guitar players from the Northeast of Brazil. This theme is a an "aboio," a work song used by cattlemen which Krieger thought would be well-suited to the viola's timbre and character (BIAGGI, 1996, p. 33). Its lyrics and translation are as follows: 


\author{
Minha mãe \\ Quando eu morrer \\ Ponha no meu mausoléu \\ Chapéu, botina e gibão \\ Gibão, Botina e chapéu \\ Pra eu correr com São Pedro \\ Nas vaquejadas do céu \\ Oh my mother \\ When I die \\ Put in my mausoleum \\ Hat, boots and jacket \\ Jacket, boots and hat \\ For me to run with St. Peter \\ In Heaven's rodeos ${ }^{4}$
}

The work was very well received by the musical community and to the composer's surprise it has become one of his most popular compositions. He considers it a simple and spontaneous piece without a preconceived formal plan other than the use of the folk theme as a recitative in the introduction. The use of the modal system throughout the piece, mostly the Aeolian mode, is a direct influence of the folk theme. The overall structure resembles a Sonata form and a Fantasie, with the use of imitation, thematic transformation and modulation. It is possible to divide the sections as: introduction, exposition, development, recapitulation and coda (BIAGGI, 1996, p. 34 and 46).

\section{Applying Coordination to Brasiliana}

The opening Recitativo (figure 2) requires a flowing sound, and this is achieved with many small releases in the body, even though the bow is sustaining through the phrase. To start the first note there is a slight upward gesture followed by a downward gesture. As the motion comes down, start breathing out before the bow touches the string. This is a cueing motion that will help set the bow on the string and start the note with the desired amount of intensity and vibrato, without forcing the sound. This gesture should be performed using the abdomen, torso, and head as described previously, it is not a mere raising and lowering of the instrument.

\footnotetext{
4 Translation by Biaggi.
} 
FIGURE 2 - Opening Recitativo of Brasiliana. The suggested motions of Coordination are marked in red.

Viola Solo
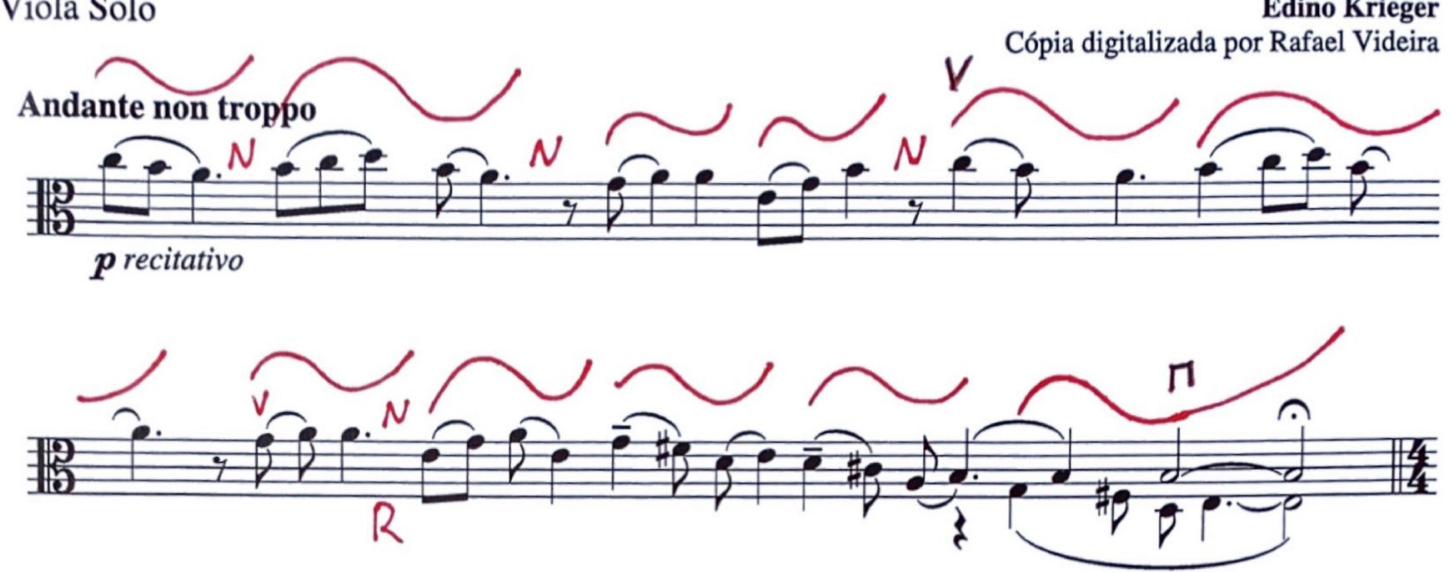

Source: digitalized copy by Rafael Videira.

The neck release (notated as $N$ ) on the third note $(A)$ is indicated to intensify and sustain the sound and vibrato in order to connect the musical line to the 3 eight-notes ascending figure (B-C-D). To do a more natural motion at the end of the $\mathrm{A}$ it is important to bring the body back from a down gesture to a centered position before the neck release. This is an example of what Dubois refers to as "filling up" the note. This type of connection will appear several times in this piece. One must also consider the whole musical phrase wherein the musical intention is directed toward a melodic arrival on the seventh note, a B that resolves in the $\mathrm{A}$. The nature of the recitative, notated without bar lines, gives the performer flexibility to shape the phrase. When the phrase occurs at other moments in the piece, the performer might choose to vary the emphasis in the phrasing.

The second entrance of the soloist is on measure 7 (Figure 3) with strong accented notes (C and G). The notated downward gestures finish with an upward gesture and an arrow. The arrows indicate that the player can consider applying short releases after each note as opposed to sustaining the sound. That will make the string resonate creating more excitement. Dubois uses that symbol to remind students to do an upward release after chords as well. Also, to initiate these notes it is important to flex the right-hand knuckles to catch the string in the lower half of the bow. The neck release was placed after the $\mathrm{F} \#$ to help connect the notes during the bow and string change.

The repulls (notated as R) in measures 12, 13 and 14 are meant to sustain the sound to project the shorter notes at the end of the slurs. The neck releases at the string crossing sequence in measures 14 and 15 assure a more vibrant sound and clean string crossings. 

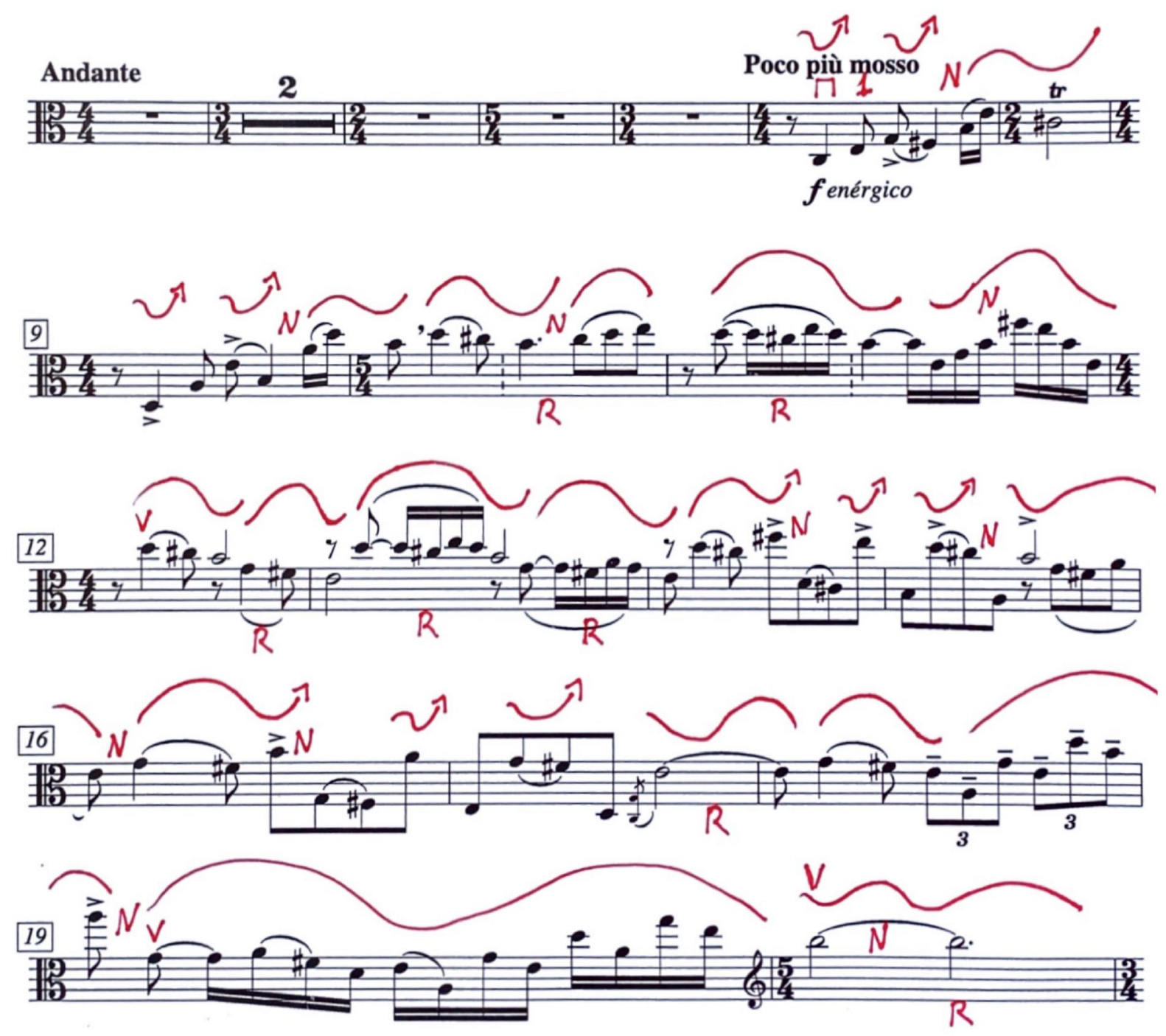

Source: digitalized copy by Rafael Videira

The phrase at measures 33-35 is similar to the beginning of the piece, however, for artistic variety it is notated slightly different. 
(2)
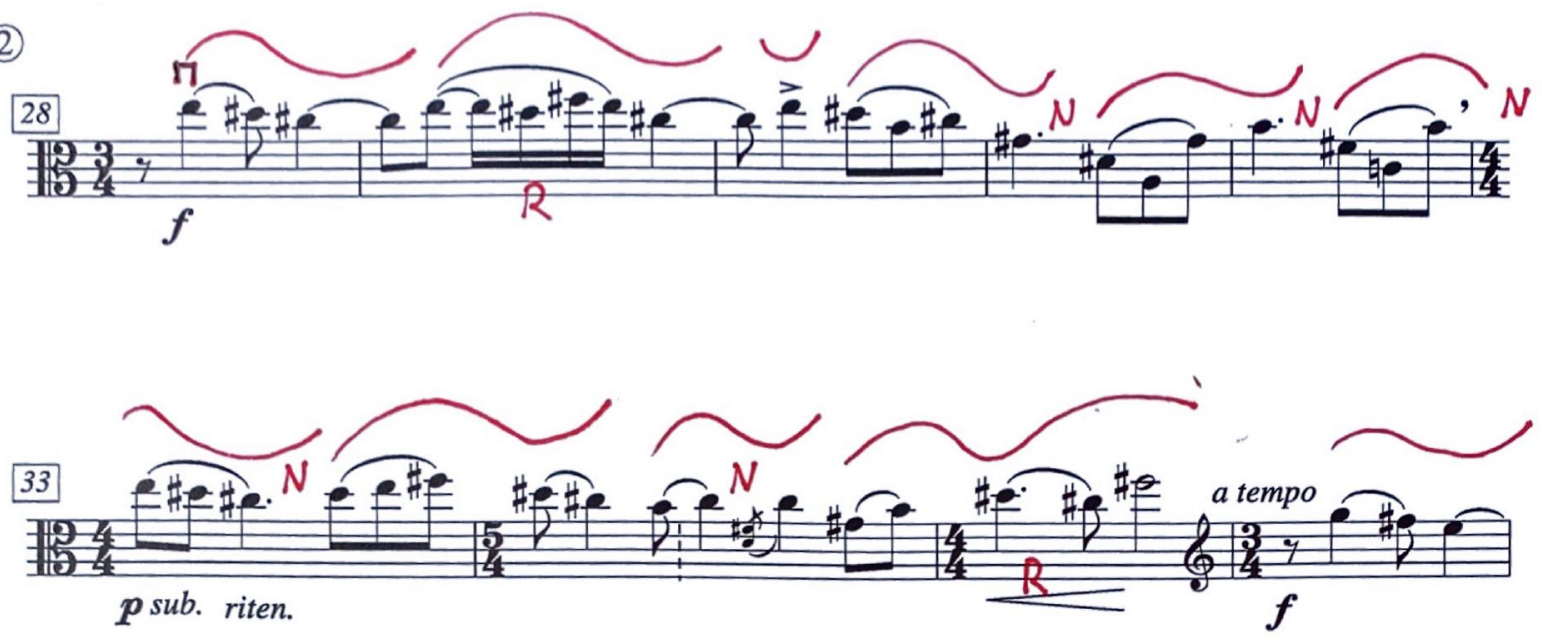

Source: digitalized copy by Rafael Videira.

On measure 52 the viola presents a new contrasting theme. With fast sixteenth-notes, it is a two-bar phrase with a crescendo that will appear several times during the piece. The notes can be organized into two groupings and the gestures are decided according to the grouping. A release on both dotted F-sharps need to happen in order to have continuity to the second group. Dubois explored two possible bowings for this passage: the first bowing was "as it comes," the second bowing placed both F-sharp and B in the same down-bow direction. Her body gestures did not change because of the bowing, the gestures were the same on both examples, evidencing that Coordination is about following the phrasing shape the interpreter wants. The bowing should only enhance the musical line.

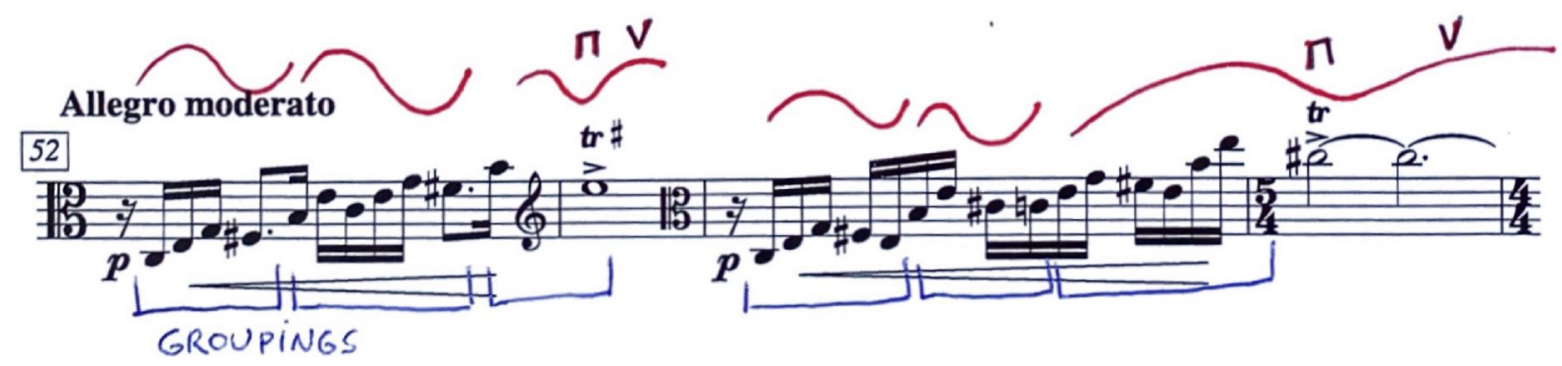

Source: digitalized copy by Rafael Videira. 
The cadenza starts at measure 95 and was written by the composer. Except for an almost exact quote of measures 14 to 17 , it explores mainly the opening three notes of the first theme. He uses these three descending notes in a polyphonic fashion with double stops creating two voices at the same time. He also presents a new element in two short sequences where the second note leaps an octave higher, thus exploring the intervals of $7^{\text {th }}$.

FIGURE 6 - The cadenza continues a musical exploration of material previously presented.

(4)

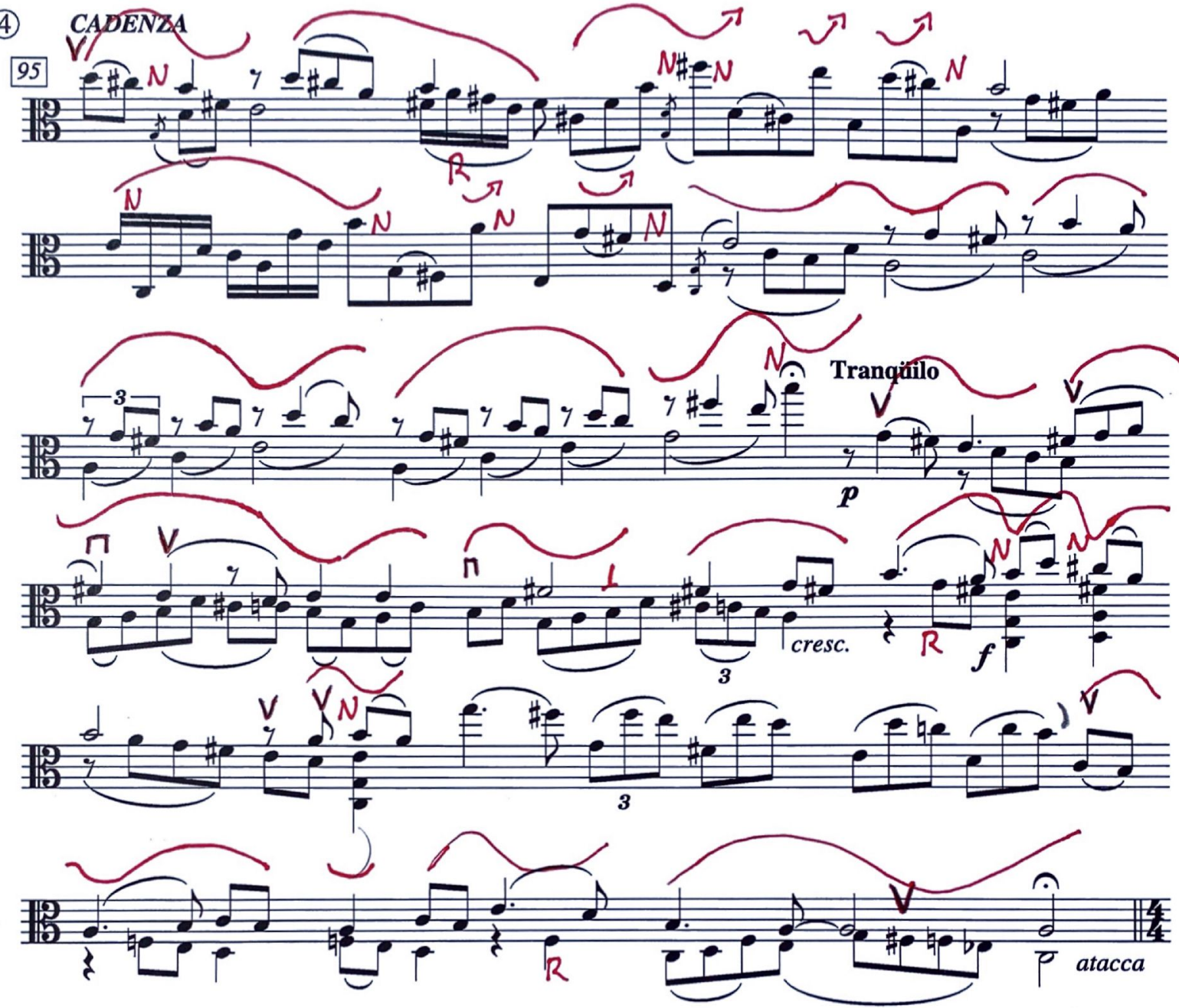

Source: digitalized copy by Rafael Videira.

After the Cadenza, there is a brief return of the Allegro Moderato from measure 52, leading to a final Vivace. At the Vivace (figure 7), the composer creates excitement with a series of repeated notes and a shift to $\mathrm{a} 3 / 4$ tempo that is best felt in one pulse per measure. To accomplish that, the gestures suggested are a downward motion in the first two eight-notes, and the rest of the measure 
follows with an upward motion, thus releasing the tension. This will create the feeling of circular motion by the bar needed for this exciting coda.

FIGURE 7 - The first measures of the Vivace.

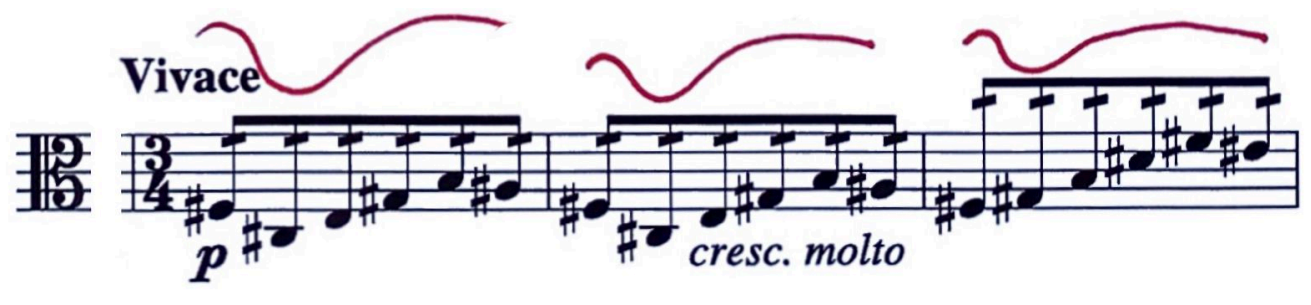

Source: digitalized copy by Rafael Videira.

\section{Conclusion}

In this study, we explored the application of Coordination techniques to a key work of the Brazilian repertoire, converging these two worlds. The markings in the score are suggestions resulting from our present study and reflect the interpretive understanding gained in collaborative dialogue between the authors and the interviewee.

As readers avail themselves of the solutions and suggestions presented here, they will do well to keep in mind the exploratory and individual nature of the application of Coordination to different works and players. It is important that the reader try these gestures while playing and even without the instrument, and also try the opposite gestures to fully grasp how the directional motions affect and create the continuum of movement. As Dubois mentioned, trying different gestures will clarify which one fits a given passage better and feels more natural. Ultimately, the goal is that this information informs performers to explore their playing, so their freedom of motion allows a strong musical interpretation through a more relaxed and fluid way of playing. We hope this work will contribute to an increasing awareness and deeper understanding of Coordination.

\section{ACKNOWLEDGMENTS}

We would like to thank Dr. Susan Dubois for her availability and willingness to share her knowledge and expertise in the research process of this article. 


\section{REFERENCES}

BARRETT, Henry. The Viola: Complete guide for teachers and students. 2nd ed. Alabama: University of Alabama Press, 1978.

BIAGGI, Emerson Luiz de. Brazilian Art-Music in The Post-Nationalist Period: Three Compositions for Viola. Doctoral Dissertation. Santa Barbara: University of California Santa Barbara, 1996.

DANE, Matthew. Coordinated Effort: A Study of Karen Tuttle's Influence on Modern Viola Teaching. Doctoral dissertation. Houston: Rice University, 2002.

DEW, Robert. In Response to Instinct - Karen Tuttle's Insights into the Coordinated Action - its Mechanisms, Articulation, and Prerequisites. The Strad, 104, no. 1241, p. 835-838, September 1993.

PIERMARTIRI, Leonardo. Interview with Dr. Susan Dubois. University of North Texas, Denton-TX, November $4^{\text {th }}, 2020$. Entrevista.

PAZ, Ermelinda. Edino Krieger: Compositor, Produtor Musical, Critico. Rio de Janeiro: SESC Departamento Nacional, 2012. Vol 2.

RODLAND, Carol. Master Class: In Honor of Karen Tuttle as She Retires. American String Teacher, 54, n.2, p. 45-47, May 2004.

SANDER, Amber. Performer's Guide to the Execution and Application of Karen Tuttle's Coordination, as Applied to Ernest Bloch's Suite Hébraïque. Doctoral dissertation. Denton: University of North Texas, Denton, 2013.

REITER, Emmanuella. Karen Tuttle's Heritage: the theory and practice of co-ordination. Boston: Allegra Print \& Imaging, 2008.

RITSCHER, Karen. An Interview with Karen Tuttle. American String Teacher, Fairfax- VA, v. 43, n.4, p. 86-91, Autumn 1993.

WEINBERGER, Rozanna. Body and Soul: Teacher Karen Tuttle Reveals How She Helps Students Play Without Pain. Strings, 13, no.4, p. 66-70, December 1998.

\section{ABOUT THE AUTHORS}

Leonardo Piermartiri holds a Doctor of Musical Arts degree from the University of Maryland, a Master of Music from the University of Cincinnati, Professional Studies degree from the Cleveland Institute of Music and a Bachelor of Music from Escola de Música e Belas Artes do Paraná. Most recently he was a visiting researcher at the University of North Texas College of Music. He is a professor at Universidade do Estado de Santa Catarina - UDESC in Florianópolis, Brazil since 2004. ORCID: https://orcid.org/0000-0002-8928-2408. Email: leopier@yahoo.com. 
PIERMARTIRI, Leonardo; GERLING, Daphne Capparelli. Karen Tuttle's Coordination applied to the performance and interpretation of Edino Krieger's Brasiliana. Revista Vórtex, Curitiba, v.9, n.1, p. 1-18, 2021.

Daphne Gerling enjoys an international career teaching, performing, and writing about the viola. Her dissertation, "Connecting Histories: Identity and Exoticism in the 1919 Viola Works of Ernest Bloch, Rebecca Clarke and Paul Hindemith (2007) is available digitally through Rice University. Daphne's travels and performances have taken her to 30 universities around the United States, and to 14 countries overseas. Dr. Gerling holds degrees from Oberlin Conservatory, the Cleveland Institute of Music, and Rice University. She is currently Assistant Professor of Viola at the University of North Texas, and Secretary of the American Viola Society. Her website is www.daphnegerling.com. ORCID: https://orcid.org/0000-0003-2504-0458. Email: daphne.gerling@unt.edu 